\title{
Pretermlerde Eritrosit Transfüzyonu ile İlişkili Risk Faktörlerinin Değerlendirilmesi
}

\author{
Evaluation of Risk Factors Associated with Red Blood Cell Transfusion in Preterm Infants
}

\section{Didem ARMAN ${ }^{1}$, Uzman Nursu KARA ${ }^{1}$}

1. Sağlık Bilimleri Üniversitesi, İstanbul Eğitim ve Araştırma Hastanesi, Çocuk Sağlığı ve Hastalıkları, İstanbul, Türkiye

\section{$\ddot{O Z E T}$}

Amaç: Preterm bebeklere yenidoğan ünitesinde (YYBÜ) yatışları esnasında çoğu kez eritrosit süspansiyonu (ES) transfüzyonu (TF) yapılması gerekmektedir. Çok düşük doğum ağırlıklı (ÇDDA) bebeklerin \%90 kadarına yaşamın ilk haftalarında bir veya daha fazla ES transfüzyonu yapılmaktadır.Çalışmamızda 34 gestasyonel haftanın $(\mathrm{GH})$ altında doğan pretermlerde ES transfüzyonu ile ilişkili olabilecek risk faktörlerini değerlendirmeyi amaçladık.

Gereçler ve Yöntem: Çalışmamıza YYBÜ'de takip edilen 34 GH altında doğan 68 bebeğin tıbbi kayıtları retrospektif olarak incelendi. Bebeklerin demografik verileri ve klinik verileri ile doğum sonrası alınan tüm kan örneklerinin sayısı kaydedildi. Bebekler TF yapılan ve yapılmayan grup olarak ikiye ayrılarak, istatistiksel olarak morbiditelerin oluşumu ve mortalite açısından kiyaslandi.

Bulgular: Çalışmaya dahil edilen 68 olgunun $35^{`} 1$ kız (\%51.4), 33 'ü (\%48.5) erkekti.

Transfüzyon alan ve almayan olguların ortalama doğum tartıları ve gestasyon haftaları sirasiyla $1301 \pm 402.8 \mathrm{~g}$ ile 1425 \pm 462.3 g. $(\mathrm{p}>0.05)$ ve $30.0 \pm 2.64$ ile $30.8 \pm 2.04$ hafta idi ( $>00.05)$. Olguların 25'ine (\%36.7) çoklu TF tedavisi uygulanmıştı. TF olan grupta birinci, ikinci ve 3 . TF günleri sirasılyla postnatal $21.4 \pm 10.9,29.6 \pm 11.6$ ve $32.83 \pm 8.9$ gün idi. $T F$ almayan ve alan grup kıyaslandığında doğum tartısı, gestasyon haftası, ventilatörde kalma süresi, hastanede yatış süresi, sepsis ve inotrop ihtiyacı açısından istatistiksel anlamlı fark bulundu $(\mathrm{p}<0.05)$. TF yapılan grupta kümülatif kan kayb1 7-14.gün aras1 anlamlı olarak yüksek saptandı $(\mathrm{p}<0.05)$. 14-28.gün arasında kümülatif kan kaybı açısından fark saptanmadı $(\mathrm{p}=0.009)$. Çoklu TF alan bebek grubunun ortalama tart1 ve gestasyon haftas1nın sirasıyla $1041 \pm 205$ gr ve $28.7 \pm 1.2$ hafta olduğu görüldü. Çoklu TF alan gruptaki bebeklerin ventilatörde kalış süreleri de istatistiksel olarak yüksekti ( $\mathrm{p}<0.05)$. PN 7.,14. ve 28. günlerde TF alan gruptaki bebeklerin tartı alımlarının daha az olduğu tespit edildi $(\mathrm{p}<0.05)$. TF alan grupta BPD görülme sıklığ 1 anlamlı biçimde yüksekti. TF alan grupta ROP sıklığı daha yüksek saptansa da istatistiksel olarak anlamlı fark saptanmadı $(\mathrm{p}>0.05)$.

Sonuç: Çalışmamızda TF alan bebeklerin doğum tartısı ve gestasyon haftasının daha düşük, ventilatörde kalma süresi,hastanede yatış süresi, sepsis görülme ve inotrop ihtiyacı sıklığının daha yüksek olduğunu saptadık.Özellikle ilk iki haftada alınan kan örnek sayısının fazla olması TF ihtiyacını arttırmakta idi. Pretermlerde ES TF ihtiyacının azaltılması için kan örneği alım sayısının azaltılması, mümkünse mikro yöntemlerin kullanılması ve invaziv olmayan monitörizasyon yöntemlerinin kullanılması gerekmektedir.

Anahtar Kelimeler: preterm, eritrosit suspansiyonu, transfüzyon

\section{İletişim}

Sorumlu Yazar: Dr. Didem ARMAN

Adres: İstanbul Eğitim Araştırma Hastanesi, Org. Abdurrahman Nafiz Gürman Cad. Etyemez, Samatya, 34098 İstanbul, Türkiye Tel: +90 (505) 6211989

E-Posta: dr_didemcaktir@yahoo.com

Makale Geliș: 09.01.2020

Makale Kabul: 06.02.2020

DOI: http://dx.doi.org/10.16948/zktipb.672462

\section{ABSTRACT}

Objective: Blood products,in particular red blood cell (RBC) transfusions (TF), are frequently administered in preterm neonates during their stay in neonatal intensive care unit (NICU). Up to $90 \%$ of very low birth weight preterm neonates receive one or more transfusions in the first few weeks of life.In our study,we aimed to evaluate the risks associated with ES transfusion in preterms born $<34 \mathrm{GW}$.

Material and Methods: 68 infants born under 34 GW were included in the study. The medical records of these infants were retrospectively reviewed.Demographic information and clinical findings of the babies were evaluated in the first week, 7-14. days and 14-21 days. The number of blood samples taken between the days were recorded.The infants were divided into two groups as transfused and non-transfused infants.Clinical outcomes were compared.

Results: Of the 68 cases included in the study, 35(51.4\%) were female and 33(48.5\%)were male.Mean birth weight of TF and non-TF group were $1301 \pm 402.8 \mathrm{~g}$ and $1425 \pm 462.3(\mathrm{p}>0.05)$ and mean gestational age was $30.0 \pm 2.64$ and $30.8 \pm 2.04$ weeks $(p>0.05)$ respectively.Twenty-five $(36.7 \%)$ of patients had multiple TF treatment.The mean weight and gestational week of the group with multiple TF was $1041 \pm 205 \mathrm{~g}$ and $28.7 \pm 1.2$ weeks, respectively.In the TF group, the first, second and third TF days were postnatal $21.4 \pm 10.9,29.6 \pm 11.6$ and $32.83 \pm 8.9$ days, respectively. There was a significant difference in terms of duration of ventilator stay, hospitalization time, sepsis and inotropic requirement when comparing TF group and non-TF group $(\mathrm{p}<0.05)$. Cumulative blood loss between $7-14$ days were significantly higher in TF group $(p<0.05)$. There was no difference regarding cumulative blood loss between 14th and 28th days $(p=0.009)$. The duration of ventilator stay of the babies in the multiple TF group was also statistically higher $(\mathrm{p}<0.05)$. At postnatal 7 th, 14 th,28th day, it was seen that the transfused group gained less weight.Bronchopulmonary dysplasia was found to be increased in TF group than non-TF group. When the groups were compared in terms of ROP, the rate was found similar in both groups $(\mathrm{p}>0.05)$.

Conclusion: In our study, we found that babies receiving TF had longer duration of ventilator stay, hospitalization, sepsis and inotropic requirement.The number of blood samples taken in the first two weeks increased the need for TF.In order to reduce the need for TF in preterms, it is necessary to reduce the number of blood samples taken by using micro methods and non-invasive monitoring.

Keywords: preterm, red blood cell suspension, transfusion

\section{GİRIŞ}

Son yıllarda preterm yenidoğanların bakım ve tedavileri ile ilgili önemli gelişmeler ortaya çıkmıştır. Bu gelişmelere bağlı olarak daha fazla sayıda preterm bebek yaşatılabilmektedir. Prematüre bebeklerin hastane kalış sürelerinin uzaması ve artmış girişimsel işlemler nedeniyle transfüzyon sıklığ $1 \mathrm{da}$ doğru orantılı olarak artış göstermiştir [1]. Aşırı düşük doğum ağırlıklı (ADDA) bebeklerin \% 90'ında, 
$<32$ gestasyonel haftada doğmuş bebeklerin ise \% 58 'inde yenidoğan yoğun bakım yatışları süresince en az bir kez eritrosit süspansiyonu (ES) transfüzyonu ihtiyacı doğmaktadır [2,3]. Preterm bebeklerde eritrosit süspansiyonu transfüzyonu endikasyonları ile ilgili kesin görüş birliği olmasa da ülkemizde Türk Neonatoloji Derneği tarafından 2016 yılında bir rehber yayınlanmıştır [4].

Yenidoğanlarda anemi etyolojisinde pekçok faktör rol almakla birlikte, flebotomi, akut/kronik kanamalara bağlı kan kaybı, hemoliz ve prematüre anemisi en sık nedenler olarak karşımıza çıkmaktadır. Son yıllarda yapılan çalışmalarda flebotomiye bağlı kümülatif kan alımının preterm bebeklerin tahmini kan hacminin yarısından fazlasının kayb1na yol açabileceği gösterilmiştir. [5-7]. Flebotomi ile kaybedilen kan volümü ile transfüzyon ihtiyacı doğru orantılı olarak artmaktadır.

Pretermlerde kan ürünleri transfüzyonu ve etkilerine ilişskin çeşitli çalışmalar mevcuttur. $\mathrm{Bu}$ çalışmaların önemli sonuçlarından birisi eritrosit transfüzyonlarının preterm bebeklerde inflamatuar yanıt oluşumunu arttırma riskini ortaya koymuş olmasıdır. $[8,9]$. Tüm bu riskler nedeniyle TF ihtiyacının azaltılması için en önemli adım iyatrojenik kan kayıplarının önlenmesi gibi gözükmektedir. İyatrojenik kan kayıplarının azaltılması bu bebeklerde transfüzyon ihtiyacını azaltmakla kalmayıp, intra-ventriküler kanama (IVK), bronkopulmoner displazi (BPD), prematüre retinopatisi (ROP) ve nekrotizan enterokolit (NEK), gibi preterm bebeklerde önemli morbidite ve mortalite nedenlerinin azaltılmasına katkıda bulunacaktır. [10-13].

Çalışmamızda 34GH'nın altında doğan pretermlerde flebotomi miktarı, ES transfüzyonu ihtiyacı ve transfüzyonla ilişkili olabilecek risk faktörlerini değerlendirmeyi amaçladık.

\section{GEREÇ ve YÖNTEM}

1 Ocak 2017- 31 Aralık 2018 tarihleri arasında hastanemizde doğan ve yenidoğan yoğun bakım ünitesinde (YYBÜ) yatırılarak izlenen $<34$ gestasyonel hafta bebeklerin yenidoğan dönemi verileri retrospektif olarak incelendi. Çalışma için hastanemiz Tibbi Araştırma Etik Kurulu'ndan etik kurul onayı alındı. Veriler hasta dosyalarından elde edildi. Bebekler transfüzyon alan ve almayanlar olarak iki ayrı gruba ayrıldı. Bebeklerin yatış tanıları, transfüzyon alan grubun transfüzyon günü, hemoglobin, hematokrit düzeyleri ve transfüzyon endikasyonları kaydedildi. Her bebek için flebotomi sayısı ve volumu her hafta için ayrı ayrı kayıt edildi. Her iki grup için intraventriküler kanama (IVK), bronkopulmoner displazi (BPD), prematüre retinopatisi (ROP), nekrotizan enterokolit (NEK), patent duktus arteriozus (PDA), sepsis varlığ1, hastanede yatış günüve ventilatörde kalma süresi incelendi.

Klinik bulgularla birlikte, sepsis belirteçlerinde yükseklik tespit edilmesi ve/veya alınan kültürlerde üreme saptanmasi ile sepsis tanıs1 konuldu. Bronkopulmoner displazi; gebelik yaş1 32 hafta ve üzerinde olan bebeklerde doğumdan sonraki 28 . günde, gebelik yaşı 32 haftadan küçük olan bebeklerde gebeliğin oluşumundan itibaren 36.hafta- da oksijen ihtiyacının devam etmesi olarak kabul edildi [14]. Prematüre retinopatisi değerlendirmesi Uluslararası Retinopati Sinıflamasına göre yapıldı [15]. Bebeklerde intraventriküler kanama kraniyal ultrasonografi ile Papile siniflamasina göre derecelendirildi [16]. NEK, modifiye Bell sinıflamas1 [17] ile derecelendirildi.

\section{İSTATİSTIKKSEL ANALİZ}

Bulguların istatistiksel analizi için SPSS (Statistical Package for Social Sciences, 20th version, USA) programı kullandı. Çalışmanın normal dağılan sayısal değişkenler ortalama \pm standart sapma, normal dağılmayan sayısal değişkenler ortanca (minimum-maksimum) şeklinde gösterildi. Kategorik verilerin değerlendirilmesi için Ki-kare testi kullanıldı. Sonuçlar $\% 95$ güven aralığında, anlamlılık $\mathrm{p}<0,05$ düzeyinde değerlendirildi.

\section{SONUÇLAR}

Hastanemizde $<34$ gestasyonel haftada doğan ve yenidoğan yoğun bakım ünitesinde yatırılan, tartı ve gestasyonel haftası eşleştirilmiş 68 olgu çalışmaya dahil edildi. Her grup 34 olgudan oluşmaktayd. Çalışma grubu ve kontrol grubunun ortalama doğum tartıları ve gestasyonel haftaları sirasıla , $1301 \pm 402.8 \mathrm{~g}$ ve $1425 \pm 462.3 \mathrm{~g} ; 30.0 \pm 2.64$ ve $30.8 \pm 2.04$ idi. Her iki grup arasında doğum tartıla$\mathrm{r} 1$ ve gestasyonel hafta açısından istatistiksel olarak fark yoktu $(p>0.05)$. Transfüzyon alan grupta ilk transfüzyon günü postnatal $21.4 \pm 10.9$ gün; ikinci ve üçüncü kez transfüzyonlar için sırasıyla, 29.6 \pm 11.6 and $32.83 \pm 8.9$ gün olarak sonuçlandı. İlk transfüzyon esnasında hematokrit değeri $25.4 \pm 3.41$ idi. Çalışma grubunda 25 (\%36.7) olgu birden fazla kez transfüzyon almıştı. Multipl transfüzyon alan olguların ortalama doğum tartıları ve gestasyonel haftaları sirasiyla, $1041 \pm 205 \mathrm{~g}$ ve $28.7 \pm 1.2$ gestasyonel hafta idi ve tek sefer transfüzyon alanlara göre anlamlı olarak düşüktü $(\mathrm{p}<0.05)$.

Postnatal haftalara göre her iki grupta alınan kan örneklerinin miktarı Tablo 1'de gösterilmiştir. Postnatal 7-14. günler arasinda transfüzyon alan grupta anlamlı şekilde artmış miktarda kan alımı olduğu görülmektedir. Postnatal 0-7. ve 14-28. günler arasında ise her iki grup arasinda istatistiksel anlamlı farklılık olmasa da transfüze olan grupta kan alım miktarının diğer gruba kıyasla artmış olduğu görülmüştür $(p>0.05)$.

Tablo 1: Postnatal günlere gore her iki gruptaki olgulardan alınan kümülatif kan miktarı.

\begin{tabular}{|r|r|r|c|}
\hline & $\begin{array}{c}\text { Transfüzyon } \\
\text { alan grup } \\
(\mathrm{n}=34)\end{array}$ & $\begin{array}{c}\text { Transfüzyon } \\
\text { almayan grup } \\
(\mathrm{n}=34)\end{array}$ & $\mathrm{p}$ \\
\hline Postnatal 0-7 gün & $11.7 \pm 4.82$ & $9.2 \pm 3.1$ & 0.08 \\
\hline (ort \pm sd) (ml) & $8.64 \pm 3.76$ & $4.36 \pm 1.97$ & 0.039 \\
\hline Postnatal 7-14 gün & $9.4 \pm 4.8$ & $7.38 \pm 3.06$ & 0.09 \\
\hline Postnatal 14-28 gün & & & \\
\hline (ort \pm Sd) (ml) & & & \\
\hline
\end{tabular}


Kümülatif kan kaybı transfüzyon alan ve almayan grupta sirasiyla, $29.05 \pm 8.0$ ve $20.4 \pm 6.1 \mathrm{ml}$ idi $(\mathrm{p}=0.03)$. Kiloya göre hesaplandiğında ise transfüzyon alan grupta $22.4 \pm 5.5 \mathrm{ml} / \mathrm{kg}$ transfüzyon almayan grupta ise $14.6 \pm 4.2 \mathrm{ml} / \mathrm{kg}$ kayıp olduğu hesapland $(\mathrm{p}=0.03)$.

Tablo 2: Her iki grubun klinik bulgulara göre karşılaştırılması.

\begin{tabular}{|l|c|c|c|}
\hline & $\begin{array}{c}\text { Transfüzyon } \\
\text { alan grup } \\
(\mathrm{n}=34)\end{array}$ & $\begin{array}{c}\text { Transfüzyon } \\
\text { almayan grup } \\
(\mathrm{n}=34)\end{array}$ & $\mathrm{p}$ \\
\hline $\begin{array}{l}\text { Ventilatörde kalış süresi } \\
\text { (gün) (ort } \pm \text { sd) }\end{array}$ & $25 \pm 1.3$ & $10 \pm 3.5$ & $<0.01$ \\
\hline Sepsis (n) & 33 & 13 & $<0.01 \chi^{2}$ \\
\hline Inotrop ihtiyacı (n) & 21 & 11 & $<0.01 x^{2}$ \\
\hline IVK (n) & 6 & 0 & $<0.01 x^{2}$ \\
\hline NEK (n) & 0 & 0 & - \\
\hline ROP (n) & 9 & 4 & 0.131 \\
\hline BPD (n) & 7 & 0 & $<0.01$ \\
\hline $\begin{array}{l}\text { Hastanede yatış süresi } \\
\text { (gün) }\end{array}$ & $62.35 \pm 28.4$ & $17.33 \pm 11.9$ & $<0.01$ \\
\hline Mortalite (n) & 2 & 0 & 0.04 \\
\hline
\end{tabular}

IVK, İntraventirküler kanama; NEK, Nekrotizan enterokolit; ROP, Prematür retinopatisi; BPD, Bronkopulmoner displazi. $\chi^{2}$ : Ki Kare testi ile çalışılmıştır

Her iki grup klinik bulgular açısından karşılaştırıldığında ventilatörde kalıs süresi, inotrop ihtiyac1, hastanede yatış süresi, sepsis, BPD ve mortalite sıklığ1 transfüzyon alan grupta anlamlı şekilde yüksek bulundu. Prematüre retinopatisi ve NEK her iki grupta benzer sikliktayd1.

Postnatal 14. ve 28. Günlerdeki tartı alımı incelendiğinde, transfüze olan grubun kontrol grubuna göre daha az tartı almış olduğu, postnatal 7 . günde ise transfüze olan grupta tartı kaybının daha fazla olduğu görülmüştür.

Tablo 3: Her iki grubun postnatal günlere göre tartı alımı.

\begin{tabular}{|l|c|c|c|}
\hline & $\begin{array}{c}\text { Transfüzyon } \\
\text { alan grup } \\
(\mathrm{n}=34)\end{array}$ & $\begin{array}{c}\text { Transfüzyon } \\
\text { almayan grup } \\
(\mathrm{n}=34)\end{array}$ & $\mathrm{p}$ \\
\hline 0-7 gün (ort \pm sd,gr) & $-135.41 \pm 46.8$ & $-88.65 \pm 13.1$ & 0.04 \\
\hline 7-14 gün (ort \pm sd,gr) & $51.08 \pm 13.5$ & $94.6 \pm 9.36$ & 0.03 \\
\hline 14-28 gün(ort \pm sd,gr) & $224 \pm 23.8$ & $305.8 \pm 17.7$ & 0.029 \\
\hline
\end{tabular}

\section{TARTIȘMA}

Anemi, YYBÜ'de tedavi gören prematüre bebeklerde sik görülen bir morbiditedir. Prematüre bebeklerde anemi gelişiminde yaşamın ilk haftalarındaki yetersiz hematopoez, artmış eritrosit y1kımı, eşlik eden enfeksiyon ve ek morbiditeler gibi pekçok faktör rol oynamaktadır. Ancak önemli başka bir neden ise laboratuvar çalışmaları için sık kan alımına bağ̣lı iyatrojenik kan kaybıdır.

YYBÜ'de yatışları sırasında preterm bebeklerde flebotomiye bağlı kan kayıplarının değerlendirildiği çalışmalara bakıldığında, bu kayıpların PN 7-70 gün arasında incelendiği ve kan kaybı miktarının da 14-98 ml gibi çok geniş bir aralıkta olduğu gözlenmektedir. Pretermlerde ES transfüzyon ihtiyacının azaltılmasıyla ilgili 2005 yılında yapılan bir çalıșmada postnatal ilk iki haftada tahmini kümülatif kan kaybının $70 \mathrm{ml} / \mathrm{kg}$ olduğu bulunmuştur [7]. Neonatal anemide transfüzyonun önlenmesi ve fle- botomi kayıplarının hesaplanmasında matematiksel bir model geliştiren Rosebraugh ve ark. ise postnatal 30 günde ortalama kan kaybının 60 ml/kg olduğunu göstermişlerdir [5]. Haiden ve ark.'nın eritropoietin uygulamasının transfüzyon sıklığ1 üzerine etkilerinin araştırıldığ çalışmalarında ise çalışma süresince (57 gün) flebotomiye bağlı kayıpların 34 ml/kg olduğu saptanmıştır [18]. 2019 yılında Counsilman ve ark. 28 gestasyonel hafta altındaki bebekleri incelemiş ve bu olgu grubunda en fazla kan kaybının postnatal ilk haftada olduğunu, kümülatif kan kaybının ise postnatal 30. günde $19.6 \mathrm{ml}(24.2 \mathrm{ml} / \mathrm{kg})$ olduğunu bulmuşlardır [19]. Çalışmamızda postnatal 30. günde flebotomiye bağlı kümülatif kaybın 29 $\mathrm{ml}(22.3 \mathrm{ml} / \mathrm{kg})$ olduğu tespit edilirken literatürdeki ortalama değerlere göre daha az miktarda kayıp olduğu gösterilmiştir. Literatürle benzer şekilde biz de çalışmamızda postnatal ilk haftada kaybın en fazla miktarda olduğunu saptadık. Diğer çalıșmalar ile karşılaştırıldığında flebotomi ile kan kaybı miktarının daha az olmasını ünitemizde postnatal 1. gün kan alımının umbilikal korddan alınan örneklerle, günlük elektrolit ve bilirubin düzeyi takiplerinin ise kan gazı değerleri ile yapılmasına bağlı olabileceğini düşünmekteyiz.

İyatrojenik kan kaybının prematürite anemisin en önemli nedeni olduğu ve flebotomilere bağlı kan kayıplarının transfüzyon ihtiyacı ile doğru orantılı olduğu bilinmektedir $[5,6]$. Transfüzyon ihtiyacındaki artış çok düşük doğum ağırlıklı bebeklerde transfüzyon ile ilişkilendirilen morbiditelerin oluşması endișesini beraberinde getirmektedir. Transfüzyon alan bebeklerde intraventriküler kanama [11] ve bronkopulmoner displazi gelişme [20, 21] riskinin arttığını gösteren çalıșmalar mevcuttur. Preterm bebeklerin, antioksidan sistemlerinin geç olgunlaşması nedeniyle oksidatif stres riski altında oldukları düşünülmektedir. Bu görüşü destekler şekilde, Hirano ve ark. transfüzyon sonrasında preterm bebeklerde transferrine bağlı olmayan serbest demir miktarının ve oksidan aktivitenin artmış olduğunu göstermișlerdir [22]. Transfüzyon sonrası oksidan aktivitenin artması sonucunda BPD sıklığının artabileceği ihtimali üzerinde durulmaktadır. Çalışmamızda da BPD sıklığı transfüzyon alan grupta istatistiksel olarak anlamlı yüksek bulunmuștur. Intraventriküler kanama ile transfüzyon ilişkisinin değerlendirildiği çalışmaların ortak özellikleri ilk haftada transfüze edilen olgularda ağır IVK riskinin artmış olduğudur [23, 24]. Christensen ve ark. daha k1sıtlı transfüzyon protokolü ile ağır IVK sılklı̆ını azalttıklarını göstermişlerdir [25]. Çalışmamızda da benzer biçimde TF alan grupta IVK'nın daha sık olduğu gösterilmiştir. Çokça tartışılan ve transfüzyonla ilişkili olabileceği öne sürülen diğer bir morbidite de NEK' dir. Pretermde NEK ve transfüzyon ilişkisini araştıran bir meta-analizde, transfüzyon ve transfüzyon ilişkili nekrotizan enterokolit (TANEM) arasındaki ilişkiye yönelik kanıt düzeyinin çok düşük olduğu bildirilmiştir [26]. Bu bilgiyi destekler şekilde çalıșma grubumuzda da her iki grupta NEK sıklığ 1 benzer bulunmuştur. ROP, transfüzyonla ilişkilendirilen bir başka önemli morbidite olup transfüzyonun ROP gelişimi üzerine etkisi ile ilgili farklı görüşler bulunmaktadır. Dani ve ark. çalışma- 
larında 1250 gram altındaki bebeklerde transfüze edilen volümün artışı ile ROP gelişimi arasında iliş̧ki olduğunu göstermişlerdir [27]. Bu çalışmanın aksine iki ayrı çalışmada liberal ve kısıtlı transfüzyon protokolleri uygulanması sonucunda ROP siklığında herhangi bir farklılık saptanmadığı gösterilmiştir [28]. Biz de çalışmamızda transfüze olan grupta ROP sıklığının artmadı ğını gösterdik.

2015 yilında on altı YYBÜ'nin dahil olduğu ÇDDA'lı bebeklerde ES TF ile ilişkili risk faktörlerinin incelendiği çalışmada mekanik ventilasyon günü, klinik sepsis varlığ 1 , hastanede kalış ve parenteral nutrisyon süresinin önemli risk faktörleri olduğu ortaya konulmuştur [29]. Biz de çalışmamızda hastanede yatış ve ventilatörde kalış süresi, inotrop ihtiyacı ve mortalite sıklı̆̆ının transfüzyon alan grupta anlamlı olarak artmış olduğunu saptadık.

Bir diğer çalışmada TF alan grupta tam enteral beslenmeye geçiş zamanının geciktiği, parenteral nutrisyon ihtiyacının ve hastanede yatış süresinin daha uzun olduğu saptanmıştır [30]. Aynı çalışmada tam enteral beslenmeye geçişin uzaması sonucunda tartı alımının etkilendiği, buna bağl1 olarak da flebotomiye bağlı kan kaybı ve ES TF ihtiyacında artış saptandığı belirtilmiştir. Bu sonuçlarla uyumlu şekilde TF alan olgu grubumuzda PN 1. Haftada tart1 kaybı istatistiksel anlamlı olarak artmıştı. Ayrıca PN 2-4. haftalar arasında ise tartı alımının anlamlı düşük olduğu görüldü. Ancak agresif enteral beslenme, tartı alımı ve ES TF ihtiyacı arasındaki ilişkinin ortaya koyulması amacıyla geniş çaplı araştırmalara ihtiyaç duyulmaktadır.

Çalışmamızda TF alan bebeklerin doğum tartıs1 ve gestasyon haftasının daha düşük, ventilatörde kalma süresi, hastanede yatış süresi, sepsis görülme ve inotrop ihtiyacı sıklığının daha yüksek olduğunu saptadık. Özellikle ilk iki haftada alınan kan örnek sayısının fazla olması TF ihtiyacını arttırmakta idi. Pretermlerde ES TF ihtiyacının azaltılması için kan örneği alım sayısının azaltılması, mümkünse mikro yöntemlerin kullanılması ve invaziv olmayan monitörizasyon yöntemlerinin kullanılması gerekmektedir.

\section{KAYNAKLAR}

1. Aladangady N, Asamoah F, Banerjee J. Blood transfusion and short term outcomes in premature infants. E-PAS 2014, p 4113252.

2. Keir AK, Yang J, Harrison A, Pelausa E, Shah PS. Temporal changes in blood product usage in preterm neonates born at less than 30 weeks' gestation in Canada. Transfusion 2015;55:1340-1346.

3. Maier RF, Sonntag J, Walka MM, Liu G, Metze BC, et al. Changing practices of red blood cell transfusions in infants with birth weights less than 1,000 g. J Pediatr 2000;136: 220-224.

4. Türk Neonatoloji Derneği Kan Üürnleri Transfüzyon Rehberi [Internet]. Türk Neonatoloji Derneği. 2016. Available from http://www.neonatology.org.tr

5. Rosebraugh MR, Widness JA, Nalbant D, Peter Veng-Pedersen. A mathematical modeling approach to quantify the role of phlebotomy losses and need for transfusions in neonatal anemia. Transfusion 2013;53(6):1353-1360.
6. Christensen RD, Carroll PD, Josephson CD. Evidence based advances in transfusion practice in neonatal intensive care units. Neonatology. 2014;106(3): 245-253.

7. Widness JA, Madan A, Grindeanu LA, Zimmerman MB, Wong DK, et al. Reduction in red blood cell transfusions among preterm infants: results of a randomized trial with an in-line blood gas and chemistry monitor. Pediatrics 2005;115(5): 1299-1306.

8. Carroll PD, Widness JA. Nonpharmacological, blood conservation techniques for preventing neonatal anemia - effective and promising strategies for reducing transfusion. Semin Perinatol 2012;36(4):232-243.

9. Howarth C, Banerjee J, Aladangady N. Red blood cell transfusion in preterm infants: current evidence and controversies. Neonatology 2018;114(1):7-16.

10. Mohamed A, Shah PS. Transfusion associated necrotizing enterocolitis: a meta-analysis of observational data. Pediatrics 2012;129: 529-540.

11. Baer VL, Lambert DK, Henry E, Snow GL, Christensen $\mathrm{RD}$. Red blood cell transfusion of preterm neonates with a Grade 1 intraventricular hemorrhage is associated with extension to a grade 3 or 4 hemorrhage. Transfusion 2011;51: 1933-1939.

12. Zhang Z, Huang X, Lu H. Association between red blood cell transfusion and bronchopulmonary dysplasia in preterm infants. Sci Rep 2014;4:4340.

13. Brooks SE, Marcus DM, Gillis D, Pirie E, Johnson MH, Bhatia J. The effect of blood transfusion protocol on retinopathy of prematurity: a prospective, randomized study. Pediatrics 1999; 104:514-518.

14. Jobe AH, Bancalari E. Bronchopulmonary dysplasia. Am J Respir Crit Care Med 2001; 163(7):1723-9.

15. International committee for the classification of retinopathy of prematurity. The International Classification of Retinopathy of Prematurity revisited. Arch Ophthalmol 2005; 123: 991-999.

16. Papile LA, Burstein J, Burstein R. Incidence and evolution of subependymal and intraventricular hemorrhage: a study of infants with birth weights less than 1500 g. J Pediatr 1978; 92: 529-534.

17. Walsh MC, Kliegman RM. Neonatal necrotizing enterocolitis: treatment based on staging criteria. Pediatr Clin North Am 1986: 33; 179 .

18. Haiden N, Schwindt J, Cardona F, Berger A, Klebermass K, Wald M, Kohlhauser-Vollmuth C, Jilma B, Pollak A. Effects of a combined therapy of erythropoietin, iron, folate, and vitamin B12 on the transfusion requirements of extremely low birth weight infants. Pediatrics 2006 Nov;118(5):2004-13.

19. Counsilman CE, Heeger LE, Tan R, Bekker V, Zwaginga $\mathrm{JJ}$, Te Pas BA. Iatrogenic blood loss in extreme preterm infants due to frequent laboratory tests and procedures. J Matern Fetal Neonatal Med 2019;1-6.

20. Collard KJ. Is there a causal relationship between the receipt of blood transfusions and the development of chronic lung disease of prematurity? Med Hypotheses 2006; 66: 355- 364. 57.

21. Cooke RW, Drury JA, Yoxall CW, James C. Blood transfusion and chronic lung disease in preterm infants. Eur J Pediatr 1997; 156: 47- 50 . 
22. Hirano K, Morinobu T, Kim H, Hiroi M, Ban R, Ogawa $\mathrm{S}$, Ogihara H, Tamai H, Ogihara T. Blood transfusion increases radical promoting non-transferrin bound iron in preterm infants. Arch Dis Child Fetal Neonatal Ed 2001; 84:188-193.

23. Wang YC, Chan OW, Chiang MC, Yang PH, Chu SM, Hsu JF, Fu RH, Lien R. Red blood cell transfusion and clinical outcomes in extremely low birth weight preterm infants. Pediatr Neonatol 2017; 58: 216-222.

24. Baer VL, Lambert DK, Henry E, Snow GL, Butler A, Christensen RD. Among very low birth weight neonates is red blood cell transfusion an independent risk factor for subequently developing a severe intraventricular hemorrhage? Transfusion $2011 ; 51: 1170-1178$.

25. Christensen RD, Baer VL, Lambert DK, Ilstrup SJ, Eggert LD, Henry E. Association among very low birthweight neonates between red blood cell transfusions in the week after birth and severe intraventricular hemorrhage. Transfusion 2014; 54: 104-108.

26. Hay S, Zupancic JA, Flannery DD, Kirpalani H, Dukhovny D. Should we believe in transfusion-associated enterocolitis? Applying a GRADE to the literature. Semin Perinatol 2017;41(1):80-91.

27. Dani C, Reali MF, Bertini G, E. M, Pezzati M, Rubaltelli FF: The role of blood transfusions and iron uptake on retinopathy of prematurity. Early Hum Dev 2001; 62: 57-63.

28. Kirpalani H, Whyte RK, Andersen C, Asztalos EV, Heddle N, Blajchman MA, Peliowski A, Rios A, LaCorte M, Connelly R, Barrington K, Roberts RS. The Premature Infants in Need of Transfusion (PINT) study: a randomized, controlled trial of a restrictive (low) versus liberal (high) transfusion threshold for extremely low birth weight infants. J Pediatr 2006; 149: 301-307.

29. Nunes dos Santos AM, Guinsburg R, de Almeida MF, Procianoy RS, Marba ST, Ferri WA, Rugolo LM, Lopes JM, Moreira ME, Luz JH, González MR, Meneses Jdo A, da Silva RV,Abdallah VO, Duarte JL, Marques PF, Rego MA, Alves Filho N, Krebs VL; Brazilian Network on Neonatal Research. Factors associated with red blood cell transfusions in very-lowbirth-weight preterm infants in Brazilian neonatal units. BMC Pediatr 2015 Sep 4;15:113.

30. Jeon GW, Sin JB. Risk factors of transfusion in anemia of very low birth weight infants. Yonsei Med J 2013 Mar 1;54(2):366-73. 